\title{
Study on Translation Aesthetics in Oil and Natural Gas Industry
}

\author{
Qifan Yi \\ School of Geosciences \\ Northeast Petroleum University \\ Daqing, China 163318
}

\begin{abstract}
As a key translation theory, translation aesthetics plays a predominant role in translations of different fields, especially in literary translation where it works best. With its extensive implementations, translation aesthetics has been applied widely in humanities, sociology, and gradually in EST (English for science and technology). While previous studies have considerably concentrated on applications of translation aesthetics in many other branches of EST, this paper will be fixed on "petroleum", that is, oil and natural gas industry, which covers aesthetic presentation in oil and natural gas EST translation from three main perspectives, i.e. the beauty of logic, the beauty of format and the beauty of content, amongst which, the beauty of logic is embodied in accuracy and standardization, the beauty of form lies in simplicity and smoothness, and the beauty of content presents in rhetoric and transferred meaning. Each of aesthetic presentation is given an appropriate example and detailed analysis. At last, some conclusions are drawn, with prospections presented.
\end{abstract}

Keywords-translation aesthetics; oil and natural gas EST; aesthetic presentation

\section{INTRODUCTION}

With the rise of energy diplomacy in great powers, the status and role of energy resources in international politics has become significantly important[1]. Therefore, oil and natural gas EST (English for science and technology) plays a vital role in worldwide energy cooperation and exchange, new energy policy formulation and development, and global resource management. As a branch of EST, oil and natural gas EST, the same as chemical engineering, electrical engineering, mechanical engineering and the like, embraces professionalism and differentiation[2]. Unfortunately, for a long time, it has been a prevailing and fossiled thought that the EST translation "does not have to pay much attention to the translation aesthetics like literary translation"[3], or "aims to enlighten readers' rationality, instead of arousing their emotions"'[4] etc, especially in the field of oil and natural gas EST translation, where very few research and application of translation aesthetics are carried out

Although oil and natural gas EST translation does not necessarily be in line with literary translation, it also needs to pursue the beauty of translation, and meanwhile enjoys its unique charm among such works. Once the beauty gets lost, the articles of oil and natural gas industry will be lame and uninteresting, in which way shall the translation aesthetics provide a powerful theoretical basis for oil and natural gas EST translation.

\section{DOMESTIC TRANSLATION AESTHETICS THEORIES REVIEWS}

The study of translation aesthetics refers to the use of basic principles of aesthetics, linguistics and culture to explore aesthetics of inter-lingual translation ${ }^{[5]}$. However, the current situations of aesthetic theoretical system for EnglishChinese translation can be described as "diversified systems from different perspectives, and distinct contents with various methods". Many works concerning translation aesthetics have been published successively, which, generally speaking, despite of small quantity, all can fill the gap in the theoretical and practical researches of translation aesthetics in China ${ }^{[6]}$. Detailedly, Z. Fu's Practical Translation Aesthetics (1993) is the first book that sets a research target and research field for the study of translation aesthetics. M. Liu's An Introduction to Translation and Aesthetics (2005), based on the basic principles of modern aesthetics, constructs the basic framework of modern translation aesthetics, which is regarded as "foundation stone of modern translation aesthetics", and, later, Translation Studies: An Aesthetics Perspective(2011) and Aesthetics and Translation A Textbook (2016), which are co-authored with Y. Zhang, are a set of translation aesthetics courses suitable for both classroom teaching and self-study or research. Besides, R. Mao's Translation Aesthetics (2005) points out that the beauty in translation comes from the sense of language, the generation of aesthetics, and the aesthetic psychological structures of translators, and it also comes from the embodiment of translation aesthetics in English and Chinese. In addition, Z. Li's Principles of Contemporary Translation Aesthetics (2013), P. Wang's Study on the Aesthetics of Tang Poetry Translation (2014) and Study on the Aesthetics of Song Lyrics Translation (2015), and G. Gong's New Theory of Aesthetic Translation (2016), all has greatly enriched and perfected the theoretical and practical researches of translation aesthetics in China.

It can be obviously seen that the theory of translation aesthetics bursts out in splendour in literary translation, which, at the same time, embraces an extremely broad applicability. As a special type of text, a combination of 
logic, rationality, and well-knit, the translation of oil and natural gas EST also embodies resemble aesthetic characteristics.

In short, to pursuit translation aesthetics of EST, is not only a literary attainment, but also a manifestation of professional competence.

\section{IMPLEMENTATION OF TRANSLATION AESTHETICS IN OIL AND NATURAL GAS EST}

According to the above translation aesthetics theories review, when given texts to translate or interpret, translators shall read carefully, get an intensive understanding and perceive, and then translate, in order to achieve translation aesthetics, with regard to beauty of logic, form and content.

\section{A. Beauty of Logic}

Oil and natural gas EST texts, cover a wide range of knowledge i.e. some common sense and principles concerning geosciences, petroleum engineering, reservoir geology, geophysics, and geochemistry, so that they are logically rigorous, well organized, and remain objective all the time. Prior to translating such texts, logical relations need clarifying first, and then to proceed step by step, in order to get an intensive understanding of full text. Grasping the whole structure of such sentences, and then to penetrate into their essence of content, according to the internal relations and logical connection, to select the target language, ensuring that the translation is consistent with the Chinese structure and custom, and reproducing the logical beauty of these texts. In brief, the beauty of logic is embodied in accuracy and standardization.

Original text: The remains of marine plant and animal life were deposited along with rock-forming sediments under the sea where they were decomposed anaerobically (without oxygen) by bacteria which changed the fats in the sediments into fatty acids which were then changed into an asphaltic material called kerogen.

Translation: 海洋动植物的遗骸和其他造岩物质一同沉积, 细菌 在海底无氧环境下进行分解, 将沉积物中的脂肪转化为脂肪酸, 进而 转化为一种励青质, 称为干酪根。

Comment: This is a so long sentence, with almost no punctuation, that at first glance, it is too difficult to distinguish these clauses. For this type of sentence, translators should cut it into parts. Where and which lead three non-defining attributive clauses, while the heads of these clauses are respectively sea or under the sea, bacteria, and fatty acids. Secondly, meanings of several terms need to determine -- rock-forming 成岩的, sediment 沉积物, decompose 分解, 降解, asphaltic material 沥青 (物) 质, kerogen 千酪根. Finally, logical relations: sediments $\rightarrow$ bacterial decomposition (without oxygen) $\rightarrow$ asphaltic material (kerogen).

Original text: This highly unsaturated material (protopetroleum) was believed to have been formed from the fatty components of the organic debris in sediments by mild thermal cracking and polymerization.
Translation: 人们一度认为, 这种高度不饱和物质（原油），是 岩石中有机残骸的脂肪成分经过缓慢的热裂解和聚合作用形成的。

Comment: As the above example, translators should first cut the long sentence into parts. Was believed to, a passive voice with the past tense, means 人们曾经认为 or 人们一度认为, and by, a preposition, explains how the fatty components form the highly unsaturated material, that is, mild thermal cracking and polymerization. Secondly, meanings of several terms need to determine -- highly unsaturated material 高度不 饱和物质, protopetroleum 原油, fatty component 脂肪成分, organic debris 有机残骸, thermal cracking 热裂解, polymerization 聚合作用. Finally, logical relations: fatty components $\rightarrow$ mild thermal cracking and polymerization $\rightarrow$ highly unsaturated material (protopetroleum).

It is obvious that the beauty of logic is embodied in accuracy and standardization, presented either in the usage of terminology or in the structure of sentence. Here are other two examples:

Original text: Keeping oil out of the water will not be purely a function of sound drilling practices, but of sound vessel traffic management, which raises a host of concerns for protection of Arctic ecosystems and for preparedness to respond in the event of a marine accident.

Translation: 为了避免海洋石油泄漏事故的发生, 不仅要求有合 理的钻井实践, 还要求有效的船舶交通管理, 这引起了人们对北极生 态系统保护和海洋事故反应准备的大量关注。

Original text: Despite the challenges, proposals are now moving forward to make the Chesapeake Bay waterfront community of Cove Point, Maryland, into a global gateway for Pennsylvania shale gas, and to turn the remote British Columbia coastal village of Kitimat into an international energy hub.

Translation: 尽管困难重重，但（美国政府）还是出台了应对方 案, 即把位于马里兰州科佛海角的切萨皮克湾水滨社区变成销售宾夕 法尼亚洲页岩气的全球门户，并将偏远的不列颠哥伦比亚海滨村庄一 一基提马特一一变成国际能源枢纽。

\section{B. Beauty of Form}

Apart from long and complicated sentences, there are also other different structure and length within oil and natural gas EST texts. Generally speaking, such texts strive to be concise and succinct, emphasizing the minimum amount of words to convey more information. Therefore, abbreviation and compound are widely adopted in oil and natural gas EST lexis, which reflect the beauty of such lexis, that is, the beauty of form, lying in simplicity and smoothness.

Original text: For the naphtha, classical techniques allow the isolation and identification of individual compounds by physical properties.

Translation: 传统的石脑油加工技术可根据物理性质识别和分离 其中的各种化合物。

Comment: The translated version is so short and smooth that everyone, whether working in this industry or not, can grasp the essence of this text meaning. Simplicity, in Chinese, is invaluable and extremely common, which can be seen 
among Chengyus (Chinese set phrase) that convey profound meanings with minimum words.

Original text: Broadly speaking, proved 'recoverable reserves' means resources where the presence of hydrocarbons has been identified, and confirmed, either by drilling or by the application of well-recognized techniques of estimation, where the technology exists for the production of the reserves, and where that production would be economic at some identified price.

Translation:广义上讲, 已探明的 “可开采储量” 应满足三个条 件：1。通过钻井或者应用公认的测定技术，证明和确认资源中含烃; 2. 可以利用现有技术来开采资源； 3 . 可以以较为经济的价格对资源 进行开采。

Comment: The head word is resources, along with three where attributive clauses. It will be much easier for readers to understand to split this long sentence into three short ones. In other words, three short sentences can sharply simplify the structure and length of the original one.

What has been distinct is that the beauty of form lies in simplicity and smoothness, which bring readers more flexible and relaxed enjoyment. Here are other two examples:

Original text: The complexity of the thin and tight reservoirs and the unknown distribution of sweet spots have challenged horizontal drilling.

Translation: 薄层和致密储层的复杂性以及甜点区分布的未知 性, 给水平钻井带来了巨大挑战。

Original text: Technology will continue to open the way for the extraction of resources in tight rocks and very deep water, sub-salt and pre-salt formations, and of methane from coal seams, as well as deep water exploration in the Arctic regions, to name a few.

Translation: 技术进步让人们能够从致密岩石、深水、次岩层和 盐下地层提取油气资源, 同时也能从煤层中提取甲烷并在北极地区进 行深海勘探。

\section{Beauty of Content}

Nowadays, literary rhetoric becomes more popular, than ever before, in EST. The art of interlace in science and engineering makes it significant that studies on rhetorical methods to translation aesthetics. Amid the process of translating, translators should be able to cope with various rhetorical methods, and employ a variety of translation techniques to match the meaning of the target article itself, so that the original text is more vivid and rhetorical. On the other hand, transferred meaning -- conversion of the original sense, then leading another understanding of meaning, makes scientific terminology more intuitive and lingo more visualizing.

Original text: When founded in the earth, gemstones are often dull-looking and rough. Cut and polished, they sparkle as with an inner fire.

Translation: 通常采自地下的宝石都是粗䊁、灰暗的，只有经过 切削和磨光，才能发光，仿佛里面有一团火焰燃烧。

Comment: In the process of simile, it is necessary to express the characteristics of the gemstone -- the burning flame, indicates that its luster is dazzling, in sharp contrast with the previous dull-looking, so that readers can clarify its specific image through the text translation.

Original text: Since the beginning of the petroleum industry in the 19th century, the large, shallow, and highquality reservoirs of oil and gas have been explored and most of the "low-hanging fruit" of world oil and gas reservoirs has been picked.

Translation: 自 19 世纪石油工业兴起以来，人们探测出许多大 型、浅层、质量高的油气藏, 并轻而易举地获得了世界各地的油气。

Comment: The phrase "low-hanging fruit", a metaphor, vividly shows the ease of oil and gas exploration and achievement, which acts much better than the simple one word "easy".

As is seen from the above examples, the beauty of content presents in rhetoric and transferred meaning, which never makes the oil and natural gas EST inferior to literature, readable, fascinating, while little entertaining. Here are other two examples:

Original text: According to one theory, this formation and breakup of a supercontinent, in geologic time, is a cyclic process caused by the earth acting as a heat engine as heat is dissipated from the earth's interior.

Translation: 根据某一理论, 在地质时期, 超级大陆形成、分 裂, 周而复始, 因为地球就像一台热力机, 在演化过程中热量会从其 内部消失。

Original text: The main effect of the shale gas 'revolution' outside North America remains likely to be on the long-term expectations -- beyond 2030 -- for the global availability of gas and for its geographic distribution.

Translation: 考虑到页岩气资源可获得量及其地理分布特征，北 美以外地区的页岩气 “革命” 仍需时日, 甚至要到 2030 年之后。

\section{CONCLUSION}

- As a significant interdisciplinary field, in China, translation aesthetics has been attached far more attention to, and applied in non-literary translation, particularly in EST, with its rapid development inevitably spreading to diverse fields of translation. Under the guidance of translation aesthetics, EST translation gradually gets away from situations of dryness and insipidness, bringing plenty of artistic and reading enjoyment to translators and readers.

- Translation aesthetics, plays an excellent part in its application in EST's branch -- oil and natural gas EST, whose aesthetic characteristics are presented in beauty of logic, form and content, amongst which, the beauty of logic is embodied in accuracy and standardization, the beauty of form lies in simplicity and smoothness, and the beauty of content presents in rhetoric and transferred meaning. It is believed that this article can, and shall, be, in some way, inspiring translators to create more excellent works in the oil and natural gas industry. 
- Strictly speaking, the scope and field of knowledge involved in the petroleum industry, is not merely limited in engineering, but also covers fields of geosciences, namely geology, geophysics and geochemistry. Therefore, while discussing the implementation in oil and natural gas EST of translation aesthetics, translators are obligated to extend to such fields in geosciences, which will greatly benefit the further development of translation in the oil and natural gas industry.

\section{REFERENCES}

[1] Y. Wang. Energy and International Politics[D]. Party School of the Central Committee of CPC, 2002.

[2] W. Xiu, H. Dong. Stylistic Features and Translation Strategies of Petroleum Technical English[J]. Chinese Science \& Technology Translator Journal, 2014, 27(4): 7-10.

[3] M. Zhang, H. Dong. Translation Aesthetics and the Translation of EST [J]. Journal of Hebei United University (Social Science Edition), 2013, 13(4):106-107.

[4] X. Fan, X. Hu, F. Li. Analysis on the translation of technical English of petroleum from aesthetic perspective [J]. Overseas English, 2015(13): 122-123.

[5] C. Cao. On EST Translation from the Perspective of Aesthetics[D]. Xidian University, 2010.

[6] X. Li. An Overview of Translation Aesthetics[J]. Overseas English, 2018(10): 117-119. 